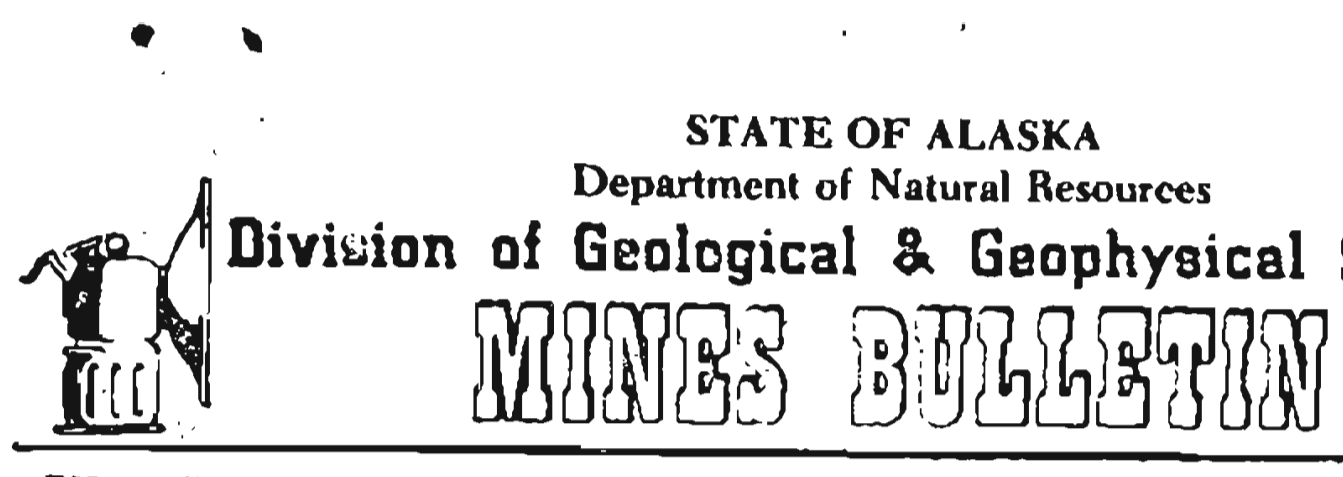

VOL. XXIIZ JANUARY

No. 1

P. O. Box 80007

College, Alaska 9y701

Published to Accelerate the Development of the Mining Industry in Alaska

Williarn A. ERan - Govemor

(:harles F. Herbert - Commissioner

Donald C. Hartman - Stale Geologiv

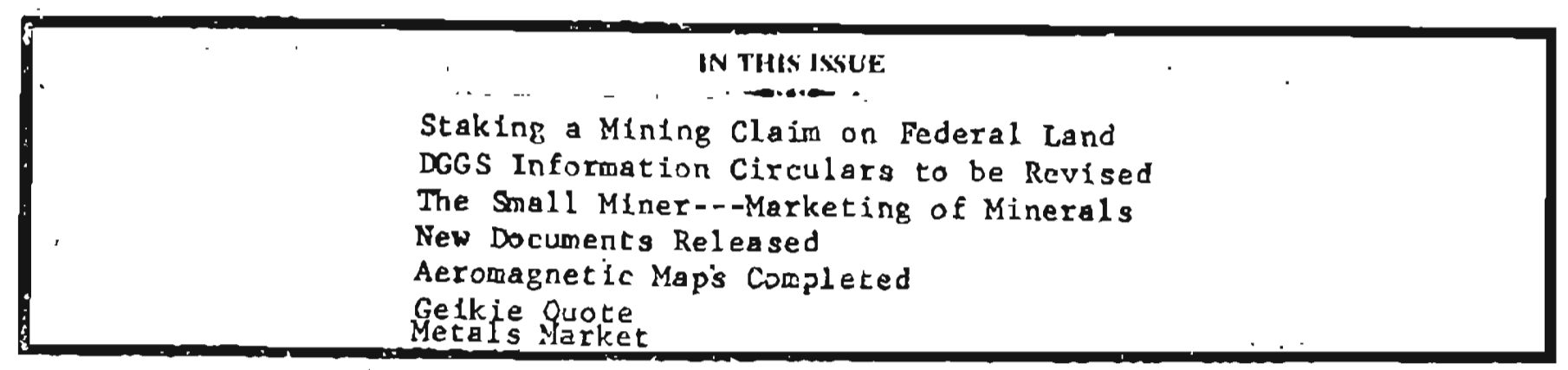

STAKING A MINING CLAR: ON PEDERAT, LAND

(Editor's note: Reprinted from ALA SKANA newspaper, (1304 W. 35th Ave., Anchorage), volume III, number 7; complled by F.S. Pettyjohn of Black Creek Mining Co.)

Thls article pertains to Federal Mining Laws only. The next issue of Algskana w11 have an article dealing with State Mining Laws.

The major problem in prospecting today is in determining which lands are open for mining locatlons and which are closed. With all of Alaska divided up inco "Natfve Lands," "Village Deficlency Lands," "D-2 Lands," "Wilderness Areas," "State Parks," "Natlonal Parks," "Reserves," "Reservations" and the "Utility Corridor," a prospector spends more tloe determining where not to go than in actual field work.

In 1872 Congress passed "An Act to Promote the Development of the Mining Resources of the United States." If you wish to file a mining claim on public domain land open to location under the mining laws, this is the law which gives you the right to do so. It is also the law which sets the linits of your rights. This mining law, together with the regulations and court decisions which have interpreted them, are collectively called the General Mining Laws. They are the rules of the game. You can't rake your own rules. If you want to see the law itself, consult the United States Code, Title 30, Sections 21-54. The regulations can be found in Code of Federal Regulations, (CFR) Title 43, Parts 3400-3600, which are available from BLM in circular form.

The words "claim" or "mining clain" have a definite meaning when used in connection with United States mining laws. These words refer to a particular piece of land, valuable for specific minerals, to which an individual has asserted a right of possesslon for the purpose of developing and extracting discovered ninerals. This right is granted the miner if he reets the requirements of the mining laws and 
these same laws guarantee him protection for 811 lawful uses of his claim for mining purposes. A mining claim is for one purpose only - to permit the development and extraction of certain valuable mineral deposits.

Staking a mining claim is neither a simple nor an inexpensive way to obtain a plece of land. The requirements of the mining laws are not easy to meet.

A mining claim may be validly located and held only after the discovery of a valuable mineral deposit.

The courts have established, and the Government follows, the "prudent man" rule to determine what is a "discovery of a valuable mineral." Under that rule "where minerals have been found and the evidence if of such character that a person of ordinary prudence would be justified in further expenditure of his labor and means, with a reasonable prospect of success, in developing a valuable mine," the requirements of the statute have been met.

There must be an actual physical discovery of the mineral on each and every mining claim and this discovery must satisfy the "prudent man" rule.

A patented mining claim refers to a piece of ground for which the Federal Government has given a deed or has passed its title to an individual. An unpatented claim is one on which an individual, by the act of valid location under the mining laws, has obtalned a right to remove the extract minerals froro the land, but where full title has not been acquired from the U.S. Government. The rights under each claim are somewhat different.

You may apply for a patent to a mining claim if you wish but it is not necessary to have a patent to mine and remove minerals from a valid claim.

If you establish a valid claim, perform and record annual assessment work reguired by state law, and meet all other requirements of Federal and state mining laws and regulations, you establish a possessory right to the area covered by the claim for the purpose of developing and extracting minerals. This possessory right may be sold, inherited, or taxed according to State law. No one else can mine, What your consent, the minerals which you have clalmed.

But until you obtain patent to the claim from the Government, you do not hold full title to the land. Your possession is based upon discovery of a valuable mineral, and your right to the clairn may be questioned by the Government if it appears your clairo lacks discovery, the minerals have been mined out, or the claim does not meet other requirements of the law.

On unpatented clairns, you may use as much of the surface and surface resources of the clairo as are reasonably necessary to carry out your mining operations. These uses, however, must be connected with and necessary for mineral development.

A mining patent or deed received from the Government gives you the exclusive title to the locatable minerals. In most such cases, you will also obtain full title of the land surface and all other resources. If you do obtain full title to the 1 and and minerals you, of course, have the exclusive right to use the surface subject to local law.

The requirements for obtaining a patent are detalled and exacting and must be fully met.

Under the provisions of the mining laws the locator or owner of a valld mining location has the right to the exclusive possession for mining purposes of the land embraced in the location, and may continue to hold such possession so long as he performs labor or makes improvements of not less than $\$ 100$ in value for the benefit of the claim each assessment year. Upon fallure to comply with the assessment work requirement during any year, the claim is open to relocation at any time prior to the resumption of work by the owner, or his heirs, legal representatives or assigns. Thus, while a valid mining claim may be held and mined under the location title, that title may be lost by failure to perform the required annual assessment work. For this reason, it is desirable to obtain a patent for the claim, after which annual assessment work is no longer required. Before a patent can be obtained, not less than $\$ 500$ must have been expended in labor or improvements in the development of the claim. 
Mining claims are of four types:

Lode claims. Deposits subject to lode clatms Include classic velns or. lodes having well-defined boundaries. They also Include other rock in place bearIng valuable minerals and may be broad zones of mineralized rock.

Placer clatms. Deposits subject to placer claims are all those not subject to lode claims. These include the "true". placer deposits of sand and gravel contalning free gold and also include many non-metallic deposits. Mill site. A mill site is a plot of unappropriated public domaln land of a nommeral character, suitable for the erection of a mill, or reduction works. Tunnel sites. A tunnel site is located on a plot of land where a tunnel is run to develop a vein or lode, or to discover veln or lode. Tunnel sites cannot be patented.

Lode claims are usually parallelograms with the longer side lines parallel to the veln or lode. They are located by metes and bounds (giving length and direction of each boundary line). They are limited by statute to a maximum of 1,500 feet in length along the veln or lode and 300 feet on elther side of the lode. Placer claims, where practicable, are located by legal subdivision (a

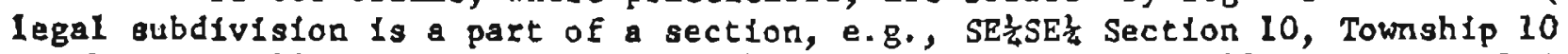
South, Range 20 East, Seward Meridian). They are limited to 20 acres per clatm per locator. However, an association of two locators may locate 40 acres, and three may locate 60 acres, etc. The maximum area is 160 acres for eight persons. Each locator should have a bona fide interest in the clain; otherwise he might be consldered a "dumy" locator and lose his rights. Corporations are limited to 20-acre clatms. On unsurveyed land and in certain other instances, placer claims may be located by metes and bounds.

Mill sites are located by metes and bounds and are limited in size to 5 acres per clain.

Tunnel sites are located by placing 2 stakes 3,000 feet apart on the 1 ina of the proposed tunnel. The miner may locate lode clatos to cover any or all velns intersected by the tunnel. This in essence gives the miner the right to prospect In an area 3,000 feet by 3,000 feet.

Most of the public lands and Natlonal Forest lands are open to prospecting under the mining $1 \mathrm{aw}$. You must determine by prospecting where the areas containing valuable minerals are situated. Only after discovery of a valuable mineral may you validly stake a mining clatm.

The Bureau of Land Management keeps up-to-date land status maps and records at 1 ts land offices. These show the current stacus of all public domain lands and minerals. These maps and records are avallable for inspection by the public, and a BIM employee will show you how this information is recorded. The office will inform you of the status of any individusl tract of land upon request.

However, information 2 zarding unpatented mining claims usually is not available in offices of the BLM or Forest Service. Such claims are recorded and/or filed in the Recorder's office in the district which the claim is located.

After determining that the land is open to location, and after doing sufficlent prospecting to determine that it contains a valuable mineral, the essential elemeats in locating a mining claim are:

1. the physical exposure or "discovery" of a valuable mineral.

2. distinctly and clearly marking the boundaries of the claim on the ground so that it can be readily identified.

3. posting the notice of location of the claim in a conspicious place, usually at the place of discovery.

4. recording an exact copy of the location in the appropriate office. In Alas$k a$, the recording office is under the District Magistrate. 
A location notice must contain the following foformation:

1. date

2. name of locator(s).

3. name of the claim.

4. whether claim is lode or placer type.

5. mineral claimed.

6. the distance claimed along the course of the vein, each way from the digcovery point and the direction (for lode clalms and placer clalms located by metes and bounds), or the acreage claimed and the legal description by particular parts of the section, township, and range (for placer claims located by legal subdivisions).

7. a connection by distance and direction as accurately as practicable from the discovery point to some well-known, permanent, and prominent natural object or landmark such as a hill, mountain, bridge, fork of a strean, or road intersection. Where a placer claim is located by legal subdivision, no other tie-in is required.

Federal law specifies only that a claim should be marked distinctly enough so it can be readily identifled. Generally, as a minfmum, all four corners of lode or placer claims, not located by legal subdivision, should be marked with posts or stone monuments.

The point of discovery of both lode and placer clalms should be marked by a post or monument. The location notice, giving information about the claim, should be placed in or on this monument.

This procedure identifies and establishes the boundaries of your clatm and is notification to others of your ciaim. The more clearly the boundaries are marked the less chance your claim will be "jumped."

At least one hundred dollars' worth of labor or improvements must be performed on or for the benefit of a clain each year. This is cailed annual asseasment work. This work must be completed on or before 12 noon on September 1 of each year. This proves your active interest in the claim and must be done to maintain your right to the claim against "fumping" or location by others.

You should also record in the Recorder's office each year a statement that you have performed the annual assessment work.

State statutes supplement the United States mining laws. These statutes specify the manner of locating a claim, marking the boundaries, recording notices of location and annual assessment work.

There is no limit to the number of claims you may hold, as long as you have made a discovery of a valuable mineral on each one and meet other requirements. Only one discovery of mineral is required to support a placer location, whether it is of 20 acres by an individual, or of 160 acres or less by an association of persons. (In Alaska, association claims for precious minerals are 1 irfted to 40 acres.)

Anyone who is a citizen of the United States, or who has declared his intention to become a citizen, may stake or locate a mining claim. Thts includes minors who are bona fide locators and corporations organized under the laws of any state.

A valid mining clatm can be bought and sold, willed or inherited. Hawever, If you buy or sell a clain, remember that you acquire or convey only such rights as you possess under the mining 1 aw.

You may bulld a house cabin or other improvements such as tool sheds or ore storage bins, etc., on a mining claim when such structures are reasonable necessary for your use in connection with your ginling operations.

A copy of the United States mining regulations may be obtained from the Bureau of Land Management, Cordova Building, Anchorage 99501 .

The most controversial of the oining laws is the provision relating to a valid discovery and the "marketability test" of the prudent-man rule. 
Many over-zealous government. exployees stfll gaintain that a valid discovery must be such that the claim can be put into production immediately. If that were the case, there would be but few claims staked as but one out of 8 million would be able to produce profitably on the day of staking, or day of discovery.

In April, 1968, the U.S. Supreme Court upheld the controversial marketability test, stating that "it is a logical complement to the 'prudent-man test" which the Secretary of the Interior has been using to interpret the mining laws."

We do not pretend to know much law, nor do we wish to interpret any, but as a person studles the traffic laws before applying for a drivers license, so too have we studied the mining laws before staking claims, and it is quite obvious that the 'marketability test' of the 'prudent man rule' of discovery has little to do with staking a gold mine in Alaska.

The marketability test of the Department of the Interlor requires that a mineral deposit be such that it can be mined profitably; if profitability cannot be shown, the discovery is not valid and the goverment may dispossess the claim owner, but, the case had absolutely nothing to do with gold, or any metal, and as this Supreme Court ruling has been used frequently to dispossess miners from vaIid gold claims, we are reprinting the Supreme Court report verbatim:

As previously stated, a discovery must be made before location but it could have been made years ago, and not by the present locator.

The Relocation law goes back to 1872 and using it, it 1 s possible to legally locate and claim, even during the winter under a deep mantle of snow, a valid mine.

Relocation of an abandoned mining claim may be done by a former owner or by any other person.

A relocation does not require a new discovery nor are new monuments necessary if the old ones are suitable. The location notice and the certificate of location must show the fact of relocation, including the Eormer name of the claim. PostIng and recording is done in the same fashion as for a newly located claim.

Frequently, old monuments are wholly or partially obliterated and it is necessary to erect new ones.

If the mining claim, tunnel site or mill site is abandoned or forfeited, all buildings and improvements are likewise abandoned and forfeited. There is no provision in law which allows a reasonable time for the former owner to remove his bulldings or improvements.

You must find gold to stake a gold mine and gold enough to make 1 t valid. Many gold bearing areas on Federal lands are still open. These areas were discovered during Alaska's early mining period but not mined at that time due to many factors only one of which was lack of sufficient gold.

Center Creek, Divide Creek and Bench Creek, as well as Skookur Creek on Placer River on the northern Kenai Peninsula, are all good and have not as yet been located. Parts of Ingran Creek, upper Placer River, the central Twenty-Mile River area and Bear Valley are all gold bearing and pay might be located. Most of Resurrection Creek above Hope is open for location providing that gold enough for a valid discovery can be found.

Quartz Creek, Kenai Lake has good gold just below the mouth of Devils Creek and there are only a few claims held. Daves Creek and Crescent Creek, both tributaries to Quartz, have had valid discoveries made on them seventy years ago and tt would be interesting to relocate them. The creeks were then named Lake Creek (Daves Creek) and Lost Creek (Crescent Creek).

There are some claims open on Stetson Creek and Coopers Creek, tributaries of the Kenal River and a few open on Mills Creek and Juneau Creek tributaries of Canyon Creek. The last three creeks named were the best gold producers on the Kenal Peninsula and some rich ground could be left; it just might pay to go and find out. 
Two of the DGGS information circulars are to be revised shortly. If you wish to have your name included (or updated) in these circulars, let us know promptly. The circulars are:

No. 8 - CONSULTANTS AVAILABLE FOR WORK IN ALASKA, Revised 11/8/72

(includes geological, engineering, mining, drilllng, assaying, metallurgical, metallogenic, prospecting, airborne).

No. 17 - COMPANIES INTERESTED IN ALASKAN MINING POSSIBILITIES, Revised 3/26/73 (please include name of company contact).

THE SMALL MINER---MARKETING OF MINERALS

(Editor's note: The following is from a series of guest articles submitted to The Mining Record by Arden L. Larson, Geologist).

At some time very early in the development of a mining property the small miner should seriously think about where to sell his product. Personally I rate the marketing of minerals as slightly more important than the ore body itself. This is the chicken and egg problem, as ore is an economic definition, you must have a market but to have a market, you must have something to sell. At any rate, the problem of finding the place to sell your product and selling it is the topic of this week's article.

Too many miners and investors have taken a market for granted. They just assume that all you have to do is mine the ore and buyers beat a path to your doorstep. In this day and age that concept is really false. Our 'friends' the environ-mentalists have given the saelters so much hell that many of them have closed down and the others have hid to spend enomous arounts of rugney to clean up their works. All of this has been needed for sume time, but not in the way it has been handled. The drastic nature of the laws enacted by the environmentalists has really clobbered the small miner. The smelters have been on reduced capacity, thus they have to meet their contracts first with the renaining capacity available for small purchases, most often the small miner. However, few smelters have had any space left for tis, thus the effect of this legislation has been to hurt the big mining companies and really kick the you know what out of the small miners. Thus, if you are a soall miner, people don't beat a path to your door, you have to go out and find them.

The first thing that you must do is to know your product. It is not enough to say that you mine lead or gold or silver. You aust be able to say, for example, that you can produce a lead concentrate of $65 \%$ lead with no copper, no $z$ inc, no silver, no gold and no sulfides, that the major mineral is lead carbonate with minor anounts of quartz and feldspar. This is, of course, the product from my mill. It 1s, however, an excellent example for illuatration of marketing efforts.

The next step is to know the uses of your product. The U.S. Bureau of Mines or U.S. Geological Survey can help you. These government agencies usually have a specialist in each mineral conmodity, thus these gentlemen can offer many ideas on marketing. Of the specialists that I know in these comodities, they are, as a group, the best workers employed by the government. Nany times these men have been involved in their specialty for over twenty years and thus know their fleld extremely well.

When searching for uses of your product don't stop with the fact that it is an ore of some metal. Did you know that galena (lead sulfide) is a lubricant? Hy point is that you just wight have a very unique property or quality in your product. Thus, through diligence in surveying a market, you may possibly find 
another place to sell your product other than a smelter. Agaln, I will ure my own mili product as an example. As stated above it is a lead carbonate concentrate. Now, when mixed with acid this concentrate dissolves readily to form a solution of lead. A clean solution of lead, as there are few impurities in the orlginal concentrate. Thus, I can sell my product to compantes making lead chemIcals for use as a starting point. Because I can replace a manufactured chemical with a natural one, I can demand a higher price than I would get from a smelter. And, because I have a natural product, my cost is less than that of the manufactured chemical thus enabling me to cut the price of the manufactured chemical. This, of course, enables me to capitalize on the unique properties of ny product.

Perhaps now is an excellent time to stress the definition of "ore." Ore is a bunch of rock that can be mined and/or processed and sold at a profit. You may have a body of $20 \%$ lead and not have ore, on the other hand, you may have a body of $1 \%$ lead and have very good ore. There is no maglc rule for determining ore from not ore. Ore is by definition an economic term.

The small miner has a basic choice, he must either sell to a large mining company or their smelter, or he must go into the marketplace and comete directly with the large mining company. However, the competition with a large company in mining is not.like it is in other industries. Each mine has its own set of geological circumstances which enable it to compete or not compete. A mine whose cost of producing a pound of lead is 3 cents will always be 1 in conpetition with other mines while a mine whose cost is 10 cents per pound will compete only during perLods of high prices. However, we small miners have one great advantage over the large mining companies. Our overhead is rather light in comparison to theirs. Did you ever see the president of one of our big brothers at the end of a shovel? Not while he was president you haven't! Most of these gentlemen know damn good and well how to use a shovel, don't kid yourself that they don't, but they began to lose touch when they started pushing papers around. On the other kand, the only way to tell the president of many suall mining companies from his crew is that he is probably a little dirtier and greasier because he is a little more enthustastic. If we sell to smelter, providing one will accept our ore, we are really sharing their problems. Now I have heard many disgruntled miners proclatm that smelters are a bunch of crooks and bandits and don't pay you for what is really in the ore. I believe that is a great injustice based on my experiences with smelters. They all have a basic problem, that of old facilities, high labor costs, high repairs, variation caused by different ores, and now pollution problems. Their only cholce is to pass the higher costs on to the ore supplier in the form of lower prices paid for ores. In comparing an old smelter schedule with a new one, I discovered that the old one pald for $92 \%$ of the lead while the new one effectively pays for $60 \%$ of the lead in the same ore. Labor costs for the old one were $\$ 3.00$ per day while the new one costs over $\$ 7.00$ per hour. As many of the smelters haven't changed during this period, their costs per pound of metal has increased enormously while their price has at best doubled for the metal. Thus they are in a squeeze and the guy who gets hurt is the miner of the metal. Hopefully, the new record prices for metals will enable the consumer to bear sane of this cost increase, thus enabling the miner to again make money. The smelter problems are also the problem of the miner, for we are all part of the same industry.

Many new revolutionary processes have been proposed to allow the small miner to sme1t his own ores and thus produce a metal to sell. Of those I know of, most are out and out frauds while the remaining are far too expensive on a snall scale to be economical. So PLEASE be wary of such magic, I feel very bad whenever I see an innocent niner spend money on something that a glib-tongued 'scientist' has sold to him.

It is most important for the small miner to first know his product, then know 
1ts uses and markets. Our current marketing efforts must lie in two directions. First is selling th a smelter and sharing their problems. Our other direction is searching for some special need that our product can supply. These are our only cholces at this time.

I belleve that the real future of the sall miner lies in us conperating together in warketing. As Ben Fronklin once said "we all hang together nr we all hang separately." My persanal research efforts have been directed at this problem. There 18 nn easy solution, but I sincerely believe that the enncept 1s sound. I would like to ask the opinions of you other small minerg nn this subject For that matter, I enfoy hearing from you and really appreciate your coments. I certalnly don't have ell of the answers, nor do I know it all. In fact, I was recently described a an over-educated miner:

\section{NEW DOCUMENTS RELEA SED}

The following new documents are avallable from the DGGS College office:

- Spectal Report 6, "Sedimentary Zeolite Deposits of the Upper Matanuska Valley," by D.B. Hawkins (of the University of Alaska Geology Department), 17 p., 3 Eigures, 1 plate. $\$ 1.00$.

- Reprint of "Geochronology of the Maclaren Metamorph1c Belt, South-Central Aleska," by T.E. Smith and D.L. Turner in Isochron/West No. 7, August, 1973, 4 pages, map. Free.

\section{AEROMAGNETIC MAPS COMPLETED}

The maps of the 1973 aermagnetic survey program have been completed by the contractor and were put ints the tail as this issue of the Mines Bullet inas going to print. The particulars of the map sale--which will cover the Big Delta, Falrbanks, Healy, and Mt. Hayes quadrangles---will be announced in the February Mines Bulletin.

\footnotetext{
"The only consolation we can find is the conviction borne In upon by ample and painful experience that a very large mass of the geological writing at the present time is utterly worthless for any of the higher purposes of the science, and that it may quite safely and profitably, both as regards time and temper, be left unread. If geologists, and especially ynung ge logists, could oaly be brought to realize that the addition of another paper to the swollen flond of nur scientiffc literature involves a serinus responsibility; that no man should publish what is not if real consequence, and that his statements when published should be si clear and condensed as he can make them, what a blessed change wnuld come nver the faces if thelr readers, and how greatly wuld they cinduce to the real advance if the sclence which they wish to serve."
} 
METALS MARRET

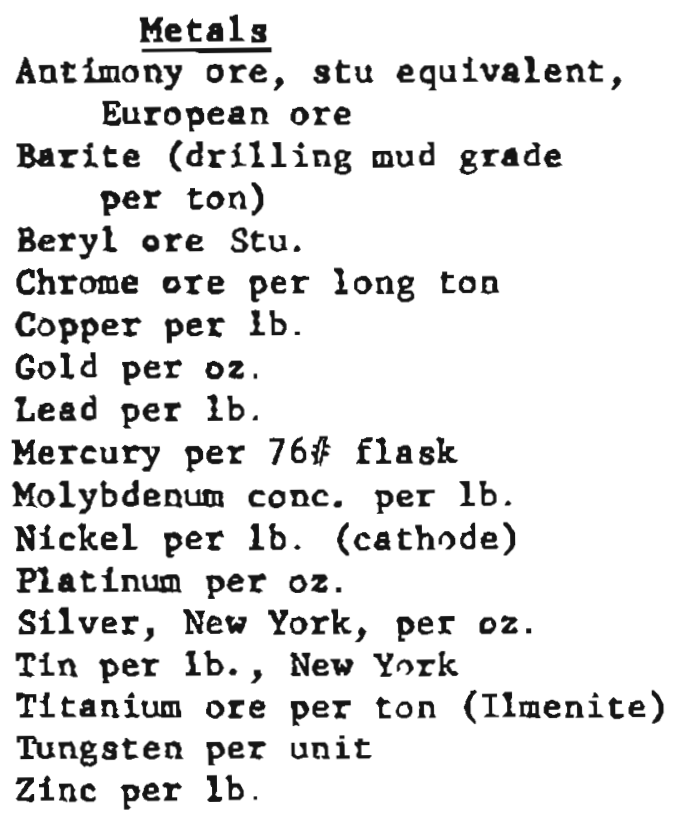

Metals

Antimony ore, stu equivalent, European ore

Barite (drilling mud grade per ton)

Beryl ore stu.

Chrome ore per long ton

Copper per Ib.

Gold per oz.

Lead per $1 \mathrm{~b}$.

Mercury per 76非 flask

Molybdenum conc. per lb.

Nickel per 1b. (cathode)

Platinum per oz.

Silver, New York, per oz.

Iin per 1b., New York

Titanium ore per ton (Ilmenite)

Tungsten per unit

Zinc per lb.

Dec. 28,1973

$\$ 17.65-18.65$

$\$ 14-18$

$\$ 30-35$

$\$ 33.00$

$68-72.24$

$\$ 111.38$

$18.40 \mathrm{C}$

$\$ 285.00$

$\$ 1.40-\$ 1.65$

$\$ 1.43$

\$158-160

$326 c$

$279.6 \mathrm{c}$

$\$ 38.00$

$\$ 46.93$

$29.6 \mathrm{c}$
Month Age

$\$ 15.15-16.15$

\$14-18

$\$ 30-35$

$\$ 33.00$

$60 c$

$\$ 90.50$

16.54

$\$ 285.00$

$\$ 1.72$

$\$ 1.53$

$\$ 160.00$

$285 \mathrm{c}$

$270 \mathrm{c}$

$\$ 32.00$

$\$ 43.00$

$21 c$
Year Ago

$\$ 7.60-8.60$

$\$ 18-22$

$\$ 24-27$

$50.6 \mathrm{c}$

$\$ 65.01$

$14.5 \mathrm{c}$

$\$ 288.00$

$\$ 1.72$

$\$ 1.53$

$\$ 141,75$ $204 c$

$177.75 \mathrm{c}$ 22-24

$\$ 55.00$

$18,32 \mathrm{c}$ 


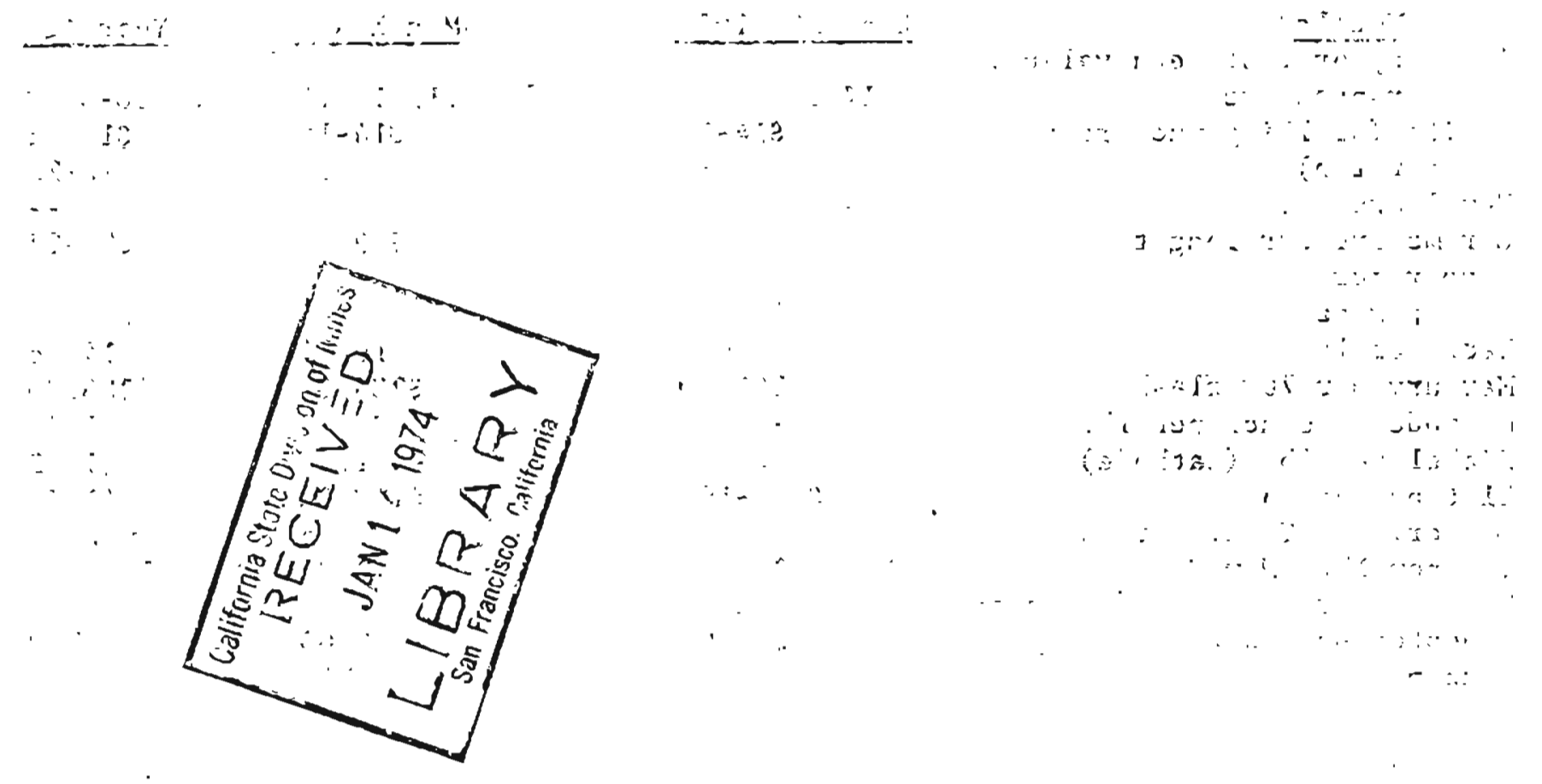

\section{State of Alaske}

Department of Natural Resources

Division of Geological \& Geophysical Surveys

P. 0. Box 80007

College, Alaska 99701

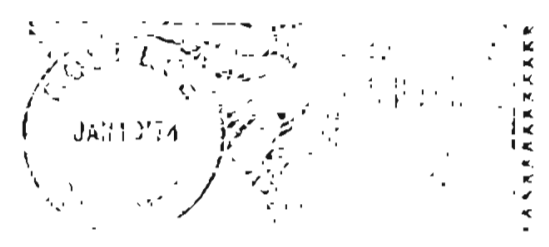

Liorory

Callf. Dlv. of Mines \& Gedory

Forry Bullding

San Franelsco,Cortionla etril

FIR S T C I A S S 